\section{Application for awards in 2014}

The Ichthyological Society of Japan (ISJ) annually presents the Young Ichthyologist Award and the Best Article Award to an eminent young ichthyologist and to authors of articles published in Ichthyological Research or in the Japanese Journal of Ichthyology, in appreciation for their achievement and contribution to ichthyology. Members of ISJ are strongly encouraged to apply for these awards.

\section{The Young Ichthyologist Award 2014}

This award is given to an ichthyologist who is less than 40 years of age as of 31 December 2013. Nominees must be society members. The prize winner is asked to make a speech on her or his achievements in ichthyology at a plenary session of the ISJ meeting 2014. The winner receives 50,000 yen and traveling expenses (up to 150,000 yen).

\section{The Best Article Award 2014}

This award is given for an article published in Ichthyological Research vol. 58(1)-60(4) or in the Japanese Journal of Ichthyology vol. 58(1)-60(2). To be eligible as nominees, at least one of the authors of the article must be a member of ISJ. Awards may be given for two or three articles from different research fields.

\section{Submission guideline}

The items listed below should be submitted in sextuplicate to the secretary of ISJ by 9 December 2013. In cases in which a nominee has no recommender, self-recommendation is possible.

Young Ichthyologist Award 2014

- Curriculum vitae

- Recommendation letter

- List of research articles

- Copies of representative articles (maximum five)

- Addresses of nominee and recommender

The Best Article Award 2014

- Nominated article

- Recommendation letter with summary of article

- Addresses of nominee and recommender

To submit a nomination, please contact:

Dr. Yoshinori Taniguchi, Secretary, ISJ

Department of Environmental Science and Technology, Meijo University

1-501 Shiogamaguchi, Tenpaku, Nagoya, Aichi 468-8502, Japan

Tel: +81-52-838-2381, Fax: +81-52-832-1179

E-mail: ytani@meijo-u.ac.jp 